\title{
THE MING COURT AS PATRON OF THE CHINESE ISLAMIC ARCHITECTURE: THE CASE STUDY OF THE DAXUEXI MOSQUE IN XI'AN
}

\author{
Hamada M. HAGRAS \\ Faculty of Archaeology, Fayoum University, Egypt \\ E-mail:hmh00@,fayoum.edu.eg
}

\begin{abstract}
The Daxuexi Alley Mosque in Xi'an was rebuilt during the Yongle reign (1402-1424).

The Jiajing Stela was erected in 1523 A.D. to record the architectural works that performed for the mosque through the ages the reconstruction of the mosque which dominated by Admiral Zheng He, who was an influential eunuch of the Ming court during the first half of the 15th century. The inscription itself was composed by another important Chinese Muslim, Hassan. The Jiajing Stele is an important document for the research of the architecture arts and history of Chinese Muslims. The author's ongoing research project attempts to examine the architecture of the Mosque during the Ming period (1368-1644). As this field of historical study lacks effective extual sources, this study uses epigraphic sources to examine historical events within the text and explain its historical value.
\end{abstract}

في عهد أسرة مينغ (1368-1644م) خلال عصر (1648)

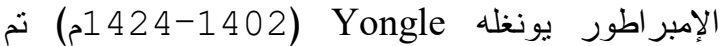
Xناء مسجد داشيشي (Mi'an Daxuexi Alley)

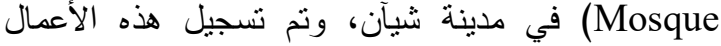

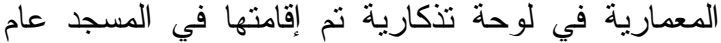

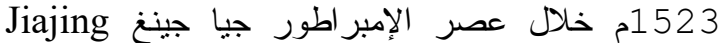
(1521-1567م). بحسب نصوص النقش فإن القائد المسلم تشنغ خه Zheng He أحد الخصيان المؤثرين في

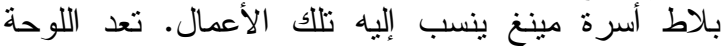

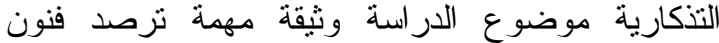
العمارة و الفنون الخاصة بالمسلمئن الصينة الصينين، كما أنها تدعو ا إلى محاولة فهم سياسة أسرة مينغ تجاههم وكذللك

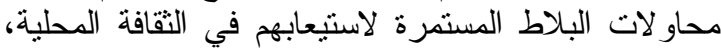

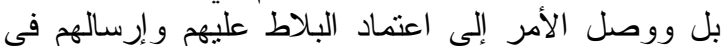

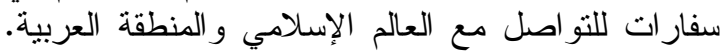

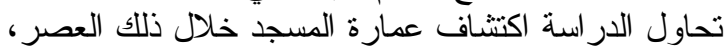

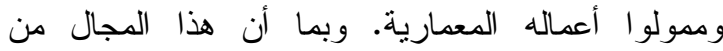
الدراسات يفتقر إلى المصادر الفعالة؛ تسعى هذه الدارة الداسة

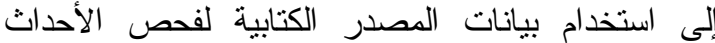
التاريخية للنص وشرح قيمتها التاريخية.

KEYWORDS

Mosque, Xi'an, Stele, Zheng He, Islamic Architecture.

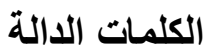

مسجد، شيآن، لوحة تذكارية، تشنغ خها لالة، عمارة إسلامية

\section{INTRODUCTION}

The Daxuexi Alley mosque, Daxuexixiang Qingzhensi-大学习巷清真寺, is located in Xi'an city in a region inhabited mainly by Chinese Muslims, in the street of Xidajie daxuexixiang 
$n e i$ (西大街大学习巷内). ${ }^{1}$ It is widely believed by Chinese scholars that the mosque was initially built in $705 .{ }^{2}$ The biggest reconstruction of the mosque happened during the reign of the Yongle Emperor of the Ming Dynasty by both Tie Xuan and Zheng He. ${ }^{3}$ However, the mosque's architectural elements are similar to Xi'an Huajuexiang mosque; the prayer hall, the qibla wall, the pavilions, the marble balustrade, the group's structural details, decorative themes, and visual aspects are dated to the reign of Jiajing. ${ }^{4}$ During the Qing Dynasty, the mosque underwent two repairs; the first in 1714 during the period of Kangxi (1661-1722), and the second in 1890 during the period of Guangxu (1875-1908). In 1956, it was listed as a cultural heritage of Shaanxi. ${ }^{5}$

\section{HISTORICAL BACKGROUND}

In 1368, the Emperor Zhu Yuanzhang-Hong Wu (1368-1398) declared the founding of the Ming dynasty. ${ }^{6}$ Contrary to the Yuan period (1271-1368); this period for Chinese Muslims was a crucial turning point in their personality as well as their culture, The Ming emperors issued a series of decrees and laws to accelerate their integration into Chinese society. ${ }^{7}$ The Emperor Zhu Yuanzhang, the founder of the dynasty, issued an edict by which foreign languages, clothes, and names were prohibited. ${ }^{8}$ This was an important step to forcibly absorb Muslims. As a result they lost their independent status. ${ }^{9}$ The Arabic and Persian languages were gradually abandoned. ${ }^{10}$ They became relatively isolated from the Muslim world.

\section{STELE OF THE DAXUEXI MOSQUE}

The Ming Chinese Stela is located in Xi'an Daxuexi Alley Mosque, inside the southern pavilion of the main courtyard, in front of the southern lecture hall. It is known by several names: Stele of Zheng He, because he financed the reconstruction process with Ming finances, and even personally supervised it, the Stele of Emperor Jiajing (1521-1567), as it was erected during the second year of Emperor Jiajing's reign, and the reconstruction Stele of Qingjing Mosque. ${ }^{11}$ The Stele's inscription in Chinese text exhibits a good deal of regularity.

Since the early 20th century, the inscriptions of Chinese Muslims have received considerable attention from researchers, and many studies have been published in English and French. Indeed, this inscription was published in 2001 by $\mathrm{Yu}$ zhen Gui and Lei Xiao Jing in their study of the stone inscriptions of Hui Chinese Muslims. ${ }^{12}$ However, the content was

\footnotetext{
${ }^{1} \mathrm{Hu}$, Islam in Shaanxi, 205.

${ }^{2}$ Chenyuning, Zhongguo huizu wenwu, 71.

${ }^{3} \mathrm{Hu}$, Islam in Shaanxi, 205.

${ }^{4}$ The Jiajing Emperor (嘉青) (1521-1567), was the 12th Emperor of the Ming dynasty, born in 1507 and dead in 1567. Jiajing was the Predecessor of the Zhengde Emperor (正德) (1505-1521) and was succeeded by Longqing Emperor (隆慶) (1567-1572). See: Mote, Imperial China, 723-724; Kangying, The Ming Maritime Trade, 57; Dardess, A Political Life, 16-20.

${ }^{5} \mathrm{Hu}$, Islam in Shaanxi, 205.

${ }^{6}$ Peter, The Mongol Empire, 205; Ebrey, Patricia B., The Cambridge Illustrated History of China, 191.

${ }^{7}$ Leslie, Islam in Traditional China, 105; Leslie, The Integration of Religious Minorities, 14; Dillon, Muslim Hui Community, 27.

${ }^{8}$ Pillsbury, Muslim History in China, 18.

${ }^{9}$ Dillon, Muslim Hui Community, 27 ; Leslie, Islam in Traditional China, 105; Benite, "Follow The White Camel", 421.

${ }^{10}$ Benite, "Follow The White Camel", 421.

${ }^{11} \mathrm{Hu}$, Der Islam in Shaanxi, 205.

${ }^{12}$ Yuzhen, "Zhōngguó huízú jīnshí lù", 185.
} 
published in simplified Chinese, without comparative research on the inscription, and neglected an analytical study of the content. ${ }^{13}$

Although the foundation inscriptions are widespread in Islamic architecture, but inscriptions in Chinese mosques are following the traditional Chinese culture of recording construction, renovation and reconstructions on stone. Initially, they were in the Arabic and Persian languages in Muslim regions and communities of the southern coast of China, such as the inscriptions preserved in the Quanzhou Qingjing Mosque (泉州清净寺), which was dominated by the Arabic language, ${ }^{14}$ as well as the inscriptions of the tomb of Bahaa al-Din in Yangzhou (扬州亦作普哈丁墓). ${ }^{15}$ However; during the Yuan period (1271-1368), the mosques included few examples of Chinese steles. During the Ming period, the inscriptions were mostly in Chinese, in line with the development of Chinese Muslim societies and forced policies by the government to integrate them.

\subsection{THE TYPE OF STELE}

Steles, the inscribed monuments on stone slabs, or tablets on wooden ones, are a Chinese tradition. ${ }^{16}$ During the Tang Dynasty (618-907) were a common social and religious tradition. ${ }^{17}$ Traditional Chinese Steles are known as bei (碑), beike (碑刻), ${ }^{18}$ and beiji (碑记 ). ${ }^{19}$ The flat stone slabs are of regular size and shape, ${ }^{20}$ generally taller than it is wide (oblong slab), standing upright, with Chinese characters carved in intaglio. ${ }^{21}$ In addition to their commemorative value, the Steles may record important events and names of officials, clerics, craftsmen, and talented writers. ${ }^{22}$ They consist of two parts: the inscription beiji (碑 文), ${ }^{23}$ and the base beizuo (碑座). ${ }^{24}$ Decorations are sometimes made up with various patterns such as flowers or dragons.

\subsection{DESCRIPTION OF THE STELE}

The Stele is a black limestone block, measuring $223 \times 83 \times 20 \mathrm{~cm}$. The inscribed Chinese text consists of 16 upright lines, containing 494 Chinese characters hanzi. The inscription includes: [1] Inscription title; [2] Names of officials and the government bureaus; [3] The initial construction of the mosque; [4] The architecture of Yuan Dynasty; [5] The maritime journey to the Arab countries; [6] The architecture of Ming Dynasty; [7] The dating formula.

\subsection{CONTENT}

\section{[1] INSCRIPTION TITLE}

\footnotetext{
${ }^{13}$ On Chinese Muslims' inscriptions, see Huart, "Inscriptions arabes et persanes", 261-320; d'Ollone, "le Islam au Yunnan", 285-329; Broomhall, Islam in China; Arnaiz, "Memoires sur les Antiquites Musulmanes", 677727.

${ }^{14}$ Liang, "Qiānnián gǔsì jīngdiăn quánzhōu”, 43.

${ }^{15}$ Lubian, "Lüè lùn sòngdài yīsīlán jiào jiànzhú" 75 .

${ }^{16}$ Chen, Zhōngguó gǔdài túxíng yìshù, 83.

${ }^{17}$ Wilkinson, Chinese History, 436.

${ }^{18}$ Jiang, Fāxiàn cáng jīng dòng, 24.

${ }^{19}$ Chongmei, "Jiāxìng fǔ jiàn zhēnjiàosì bēijì", 29 .

${ }^{20}$ Wong, Chinese Steles, 2.

${ }^{21}$ Wilkinson, Chinese History, 436; Wong, Chinese Steles, 1.

${ }^{22}$ Wilkinson, Chinese History, 436.

${ }^{23}$ Huang, "Sòngdài jiātíng duìyú fójiào sìyuàn de gòngyăng", 1-24.

${ }^{24}$ Liuwei, Ningxià huizú, 88.
}

- 136 - DOI: $10.36816 /$ shedet.006.08 


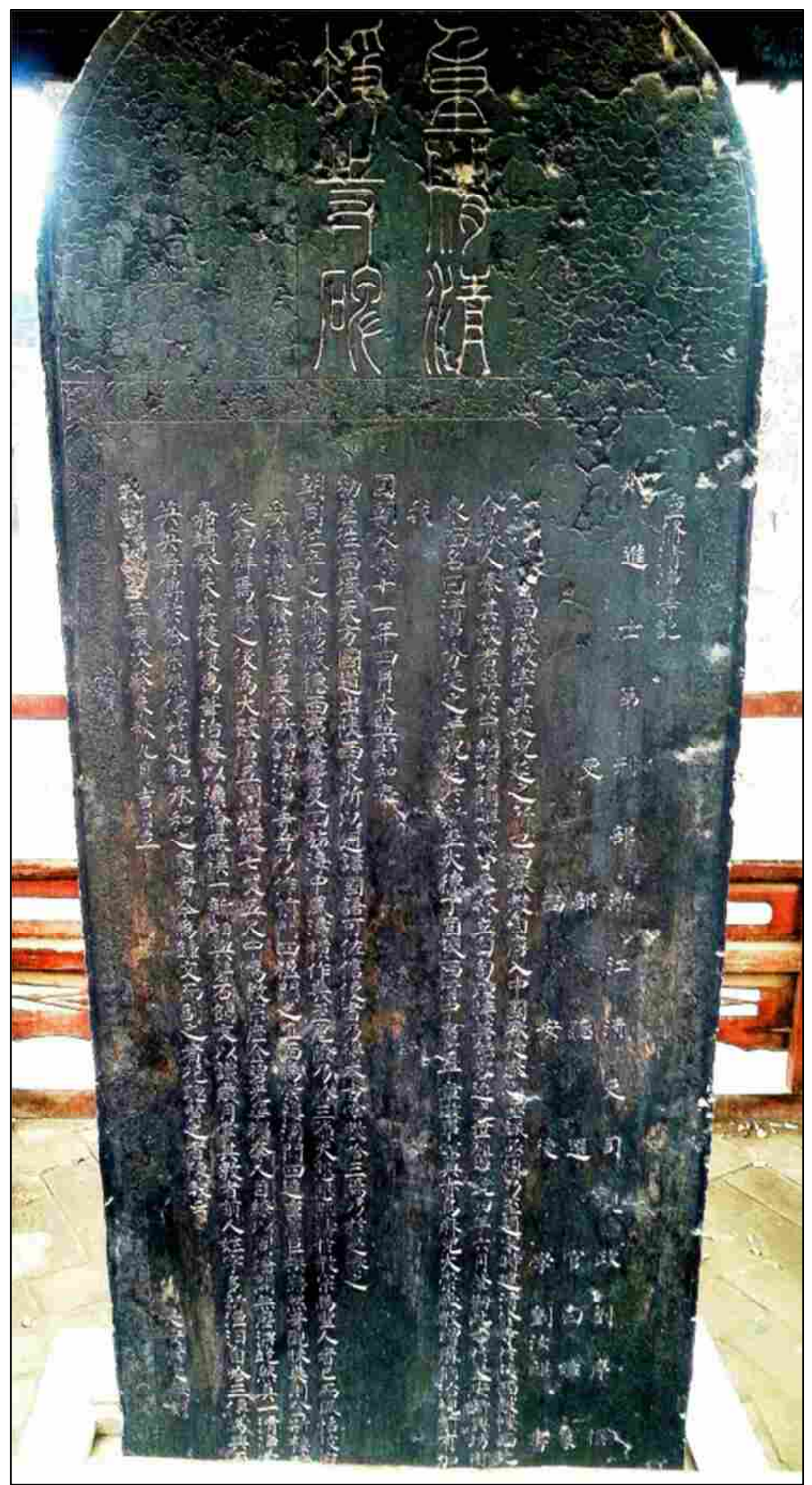

The Jiajing Stela of the Daxuexi Alley Mosque in Xi'an 
The Stele follows the type of reconstruction Steles jianxiubei (建修碑) which usually start with the word "reconstruction" chongxiu (重修). ${ }^{25}$ The aim of it is to record construction and repairs works, and also record the most important financial sponsors who contributed to the works. The top of stele carved with Chinese for "Reconstruction Stele of Qinging Mosque", Chongxiu qingjingsi bei (重修清淨寺碑). ${ }^{26}$

\title{
[2] OFFICIALS AND GOVERNMENT BUREAUS
}

\begin{abstract}
“賜進士第刑部浙江清吏司觀政劉序撰吏部㯖選官白璋篆西安後 學劉汝鹿其書”

"Jinshi degree (進士) ${ }^{27}$ former first-degree candidate) was awarded to Liu Xuzhuan (刘序撰) who owns the degree of Guanzheng (觀政). ${ }^{28}$ The Ministry of Punishments Xinbu (刑部). ${ }^{29}$ The Bureau or Division of Zhejiang province Zhejiang Qinglisi (浙江清吏司). Ministry of Personnel Libu (吏部), ${ }^{30}$ Baizhang Zhuan (白璋管) the government official for the selection, and Liu Ruqi (劉汝麒) who owns the degree of Houxue (後學). ${ }^{31}$ Xi'an”
\end{abstract}

The text has been initiated with the names of government officials and official bureaus responsible for the implementation of the inscription: Liu Xuzhuan (刘序撰) of Ministry of Punishment, Baizhang Zhuan (白璋篆) of Ministry of Personnel, and Liu Ruqi (劉汝麒). Certainly, including in the text the names of governmental offices was done to legitimise the

\footnotetext{
${ }^{25}$ Chongmei, "Jiāxìng fǔ jiàn zhēnjiàosì bēiji”, 29.

${ }^{26} \mathrm{Hu}$, Der Islam in Shaanxi, 205.

${ }^{27}$ Jinshi Degree (進士) is one of the Chinese Civil Service or the Imperial examination system Keju (科舉), which was the traditional method of selecting scholars and candidates for the state bureaucracy. This system first appeared during the Han Dynasty (206BC-220AD). It has formed throughout history and developed into a significant social phenomenon. In 1905 the examination system was abolished in an attempt by the Qing Dynasty (1622-1912) to modernize, while the civil service system was terminated with the overthrow of the Qing Dynasty in December 1911. See Yu, "Chinese Poetry", 57; Wang, The Chinese Imperial Examination System, 4; Franke, The Reform and Abolition, 70-71. By the Ming dynasty, the Jinshi degree was the highest in the examination system. Sign of the importance of the Jinshi degree, it became a symbol of the status of Chinese society. Its holders were not only center stage in ceremonies for the successful candidates from the imperial examination, but held many important positions in the state bureaucracy. See Wang, Rui, The Chinese Imperial Examination System, 85; Yang, "Míng qīng huízú jìnshì kăo lüè”, 26-34; Zhou, Chen, Qi, Zhōngguó gǔdài zhèngzhi, 88; Clark, Portrait of a Community, 40; Miyazaki, China's Examination Hell, 18-25; Park, Art by the Book, 13; Wu, Mingdài jìnshi, 365.

${ }^{28}$ Guanzheng is a degree ranked after the degree of Jinshi; it entitles the holder to be a government employee. This degree began in year 18 of the reign of Emperor Hongwu (1368-1398). See Frederic, The Great Enterprise, 953; Adam, "The Practical Training of Government Officials", 83.

${ }^{29}$ During the Ming Dynasty, the Ministry of Justice or punishment of imperial China is one of the six ministries. All were administratively followed by the State Affairs Department. These ministries are: Ministry of Official personnel affairs, Ministry of Revenue, Ministry of Rites, Ministry of War, Ministry of Punishment, and Ministry of Works. See Liu, Study on the Auditing System, 25; Dennis, Writing, 110; Yu, Chang'an Avenue, 17.

${ }^{30}$ The Ministry of Personnel was one of six ministries subordinate to the Ming Dynasty government. It was generally entrusted with the selection of employees, such as appointments, promotions, salaries, vacations, and retirement. In addition, it was entrusted with honoring official and sub-official functionaries. This ministry was of great importance and became the doyen of all ministries. See Twitchett, Mote, The Cambridge History of China, 83; Zhengyuan, Autocratic Tradition, 74.

${ }^{31}$ The degree of Houxue is a scientific degree, referred by researchers when communicating to impart modesty to themselves. See Davies, Voicing Concerns, 21; Cheng, the Use of Mao, 168.
}

- 138 - DOI: $10.36816 /$ shedet.006.08 
erection of the stele under the supervision of the Ming court. It shows that it was an official inscription.

\title{
[3] THE INITIAL CONSTRUCTION
}

\begin{abstract}
“西域教率其徒祝延之所也西域教自唐入中國厥徒奉之亟誠亟慎 乃至趙宋時建清修寺於陝西鼓樓西北隅會城人奉其教者萃於中翻 譯誦拜然沓來林立訇氬踵接莫能容”

"The Xiyujiao [Islam $]^{32}$ has widely widespread in all regions. Islam Xiyujiao has arrived in China during the Tang Dynasty. ${ }^{33}$ The believers were sent up to the Song Dynasty. ${ }^{34}$ The mosque was built in Shaanxi (陝西) in the northwestern corner of the drum tower. Clerics settled in the centre of the city and established a community of them, they translated the worship and religious rituals for the inhabitants of the city and they were free to travel and come back".
\end{abstract}

The term Xiyujiao (西域教) literally means the Western religion. IT first appeared in the historical sources of the Tang Dynasty to refer to Islam. The term is made of xiyu (西域), which was a historical term during the Han and Tang dynasties referring generally to the regions west of China; and of jiao (教), which literally means religion. xiyujiao was thus a substitute for the contemporary term yisilanjiao (伊斯兰教). Xiyujiao has spread in the Chinese Islamic inscriptions from the Yuan Dynasty to the Qing Dynasty. Islam in China is also known as qing zhen jiao (清真教), the Pure and True religion, ${ }^{35}$ as well as the term of huijiao, huihuijiao (回教-回回教), ${ }^{36}$ the religion of Hui minority, ${ }^{37}$ which was widely referred to in inscriptions of Chinese Muslims during Ming and Qing periods.

It appears that Chinese Muslims felt stable enough during the Ming period and began to participate in the administration; society also regarded them as Chinese rather than foreigners fanke (蕃客) during the Tang and Song periods, as well as Semuren during Yuan period. According to previous text, from the early Ming period, Chinese Muslims had an urgent need to trace their history and the history of Islam in China for the purpose of recording it, for fear of oblivion, especially after the forced assimilation policy adopted by the political regimes

\footnotetext{
${ }^{32}$ On the term of Xiyujiao. See Tikhvinskī̌, Perelomov, China and Her Neighbors, 124; Gregoratti, "The Parthians between Rome and China", 109; Yu, A History of the Relationships, 348; Crespigny, Fire over Luoyang, 140. Bowman, Trade, Commerce, 459.

${ }^{33}$ The Tang dynasty (唐朝, 大唐) (618-907) was a Chinese dynasty preceded by the Sui dynasty (隋朝) (581-618). Its capital was Chang'an (长安), Xi'an (西安). The dynasty was founded by Li Yuan- Gaozu (李婣祖) (r. 618626), his descendants continued to rule China for a period of three centuries, and were followed by the Five Dynasties and Ten Kingdoms period (五代十國) (907-960). See Adshead, T'ang China, 40-41; Ebrey, ed, East Asia, 90-91; Drompp, Tang China; Kurz, China's Southern Tang.

${ }^{34}$ The Song dynasty (宋朝) (960-1279) was founded by Emperor Taizu (太祖) (960-976). The history of Song dynasty is divided in two periods, Northern Song (北宋) (960-1127) and Southern Song (南宋) (1127-1279). In 1127, the Jin dynasty replaced the Northern Song dynasty, and in 1279, the Mongols, led by Kublai Khan (1260-1294), invaded the Southern Song dynasty. See Lorge, The Reunification of China, 4-5; Rossabi, Khubilai Khan.

${ }^{35}$ Gladney, "Islam and Modernity in China", 196; Gladney, Muslim Chinese, 12-13.

${ }^{36}$ Gladney, Muslim Chinese, 16.

${ }^{37}$ Hui minority huizu (回族) is the most numerous and widespread Muslim minority in China, comprising half of China's Muslim population, its population ranks the fourth after Han, Zhuang, and Man minorities. See Liuzhi, Zhōngguó yīsīlánjiào, 2; Marshallsay, "Between The State", "Between The State and Islam", 1.
} 
since the Ming Dynasty. ${ }^{38}$ The text provides a description about the way in which Islam arrived at Chang'an, the capital of China during the Tang dynasty, and how the early Muslims established a settlement during the Tang Dynasty, according to historical records Such as the Old Book of Tang Jiutang Shu (舊唐書), and Xintang Shu (新唐書), the New Book of Tang; ${ }^{39}$ In $651 \mathrm{AD}$ during the summer of the second year of the reign of the Emperor Gaozong (高宗) (649-683), Xi'an was the first Chinese city to which Islam arrived; ${ }^{40}$ this is demonstrated by the first arrival of an Islamic embassy to Tang's court in Chang'an. ${ }^{41}$

The text also indicates the earliest Islamic communities in Chang'an (Xi'an) and suggests that these enclaves were a result of the migration of large numbers of Western Muslims to China. There seems to be a consensus between the text and historical records. Although China has never been bordered by an Islamic state, it has been a destination for Muslim clerics and Imams who spread in most of China's provinces. ${ }^{42}$ The historical sources reported the arrival of four Sahabah to China during the Tang dynasty (618-907). ${ }^{43}$ Muslim migrations to China were not limited to religious motives; political motives and relations played an important role. The most important diplomatic relations between Arabs (Abbasid Caliphate) and Chinese (Tang dynasty) occurred in 757 when Emperor Suzong (756-762) asked the Abbasid Caliphate al-Mansur (754-775) some support to quell an internal revolt by the Tatars, and the Caliph sent 10,000 soldiers in a military campaign. The forces succeeded in their mission. Most of the soldiers stayed in China and did not return to their homeland. They formed their own communities, merged into the existing ones and married Chinese individuals. ${ }^{44}$ In 1070 , the Emperor Shen Zong of Song (1067-1085) hired a group of Arab mercenaries under the leadership of Prince Sayyid Sofeier to assist him in his war against the Liao dynasty (9161125), and the Emperor granted them the right to settle in China. ${ }^{45}$

Historically, this mosque is the oldest mosque built in the city, according to the text. The Qingjing mosque was initially built during the Tang dynasty. Indeed the mosque has an inscription made in Tianqi reign (1620-1626), stating explicitly that the mosque was built during the era of the Emperor Zhongzong (705-710). ${ }^{46}$

\footnotetext{
${ }^{38}$ On the earliest Muslims communities in China, see Yin, China's Minority Nationalities, 96; Benshe, Yīsīlán jiào jiànzhú, 10; Wang, "Growth and Decline", 104-122.

${ }^{39}$ The first Islamic embassy in China was recorded in both of the Old Book of Tang and the New Book of Tang. The following is from volume 198 Xiyu (西域) of Old Book of Tang “大食國 本在波斯之西。自立為王。波斯、拂菻各遣兵討之 皆為所敗。.......永徽二年, 始遣使朝貢。其王姓大食氏 名颔密

莫末淢 自雲有國已二十四年 (In the second year of the Younghui era, the Arabs began to send ambassadors from Amir al-Mu'minin the King of the Arabs. The Arabs sent these ambassadors thirty-four years after the founding of the kingdom). The following is from volume 221 xiyu (西域) of New Book of Tang “永徽二年, 大食王攽密莫末䁲始遣使者朝貢 自言王大食氏” (during the second year of the Emperor Gaozong - Yong Hui era (永徽)-, the court received an official Arab envoy, and the Arabs give greetings from the king of the Arabs to the Emperor). See Houjin, Liuxu, Jiutang shu; Songouyang, Songqi, Xintang shu.

${ }^{40}$ Leaning, Pratt, "Islam in China", 308-335; Steinhardt, "China's Earliest Mosques", 330-361; Chenyu, Zhōngguó huízú wénwù, 15; Xuezong, “dá luó sī zhī zhàn lìshǐ sùyuán”, 85-100.

${ }^{41}$ Leaning, Pratt, "Islam in China", 308-335; Steinhardt, "China's Earliest Mosques", 330-361; Chenyu, Zhōngguó huízú wénwù, 15; Xuezong, "dá luó sī zhī zhàn lìshǐ sùyuán”, 85-100.

${ }^{42}$ Benite, "Follow The White Camel", 409; Benite, "Even unto China", 93-114.

${ }^{43}$ Lixing, "Quánzhōu yīsīlán jiào yánjiū", 70.

${ }^{44}$ On the Sino-Arab relations during Tang dynasty, see Wahby, Islamic Architecture in China, 11-12.

${ }^{45}$ Israeli, "Islam in China", 253.

${ }^{46}$ Chenyu, Zhōngguó huizú wénwù, 71.
}

- 140 - DOI: 10.36816/shedet.006.08 


\title{
[4] THE ARCHITECTURE OF YUAN
}

\begin{abstract}
“迨元世祖中統四年六月肇創此寺於長安新興坊街西東面名曰清 淨分徒之半祝延於斯至大德丁酉陝西行中書省平章政事賽典赤烏 麻兒大崇厥教增廣飾治視前有加”

"During the Yuan dynasty, in [1263] the sixth month of the fourth year of the reign of Emperor Kublai Khan-Shizu (世祖-中统), ${ }^{47}$ the temple in Xinxing Square of Chang'an (長安) was rebuilt, on the street that extends from west to east, which is known as Qingjing (清 淨). In the year of dingyou (丁酉) ${ }^{48}$ [1297] of the period of dade (大 德) ${ }^{49}$ [1297-1307] by Sayyid Ajall (大崇厥教) Shams al-Din Omar ( 賽典赤烏麻兒), who was posted as the rank of Minister in the Department of State Affairs Pingzhang zhengshi (平章政事) of the Shaanxi Branch Secretariat Shaanxi Xingzhong shusheng (陝西行中 書省). He also boosted the local administration and peace compared to what had been before".
\end{abstract}

With the rise of the Yuan dynasty (1279-1368), Chinese Muslims were granted more political and economic privileges as a result of their military contributions to the Mongol army ${ }^{50}$ Kublai Khan (1260-1294) had issued a decree stating that Muslims are second only after the Mongols themselves in the Mongol Empire. ${ }^{51}$ The Mongol Emperors relied on them to control the country, and the access to such privileges was not available to others. ${ }^{52}$ It is, therefore, not surprising that the three Mongol fronts of Kublai Khan in his war against the Song were commanded by three Muslims; ${ }^{33}$ one of them was Sayyid Ajall Shams al-Din $\mathrm{Omar}^{54}$ (大崇厥教賽典赤烏麻兒), who was mentioned in the stele.

\footnotetext{
${ }^{47}$ Emperor Kublai Khan is the fifth Emperor of the Mongols (1260-1294) and the first Emperor of the Yuan Dynasty in China (1279-1294). He took over from his brother Mongke Khan. In 1271, Kublai Khan founded Yuan Dynasty in China. See: Man, Kublai Khan; Rossabi, Khubilai Khan; Clements, A Brief History of Khubilai Khan.

${ }^{48}$ Dingyou (丁酉) is the year following the era of Dade (大德) of Emperor Temür Khan Cheng Zong (成宗) (1294-1307). See Taozi, Liăng sòng yuán, 82; Chen, Jiănpǔzhài shǐ, 59; Fanyong, Shì dà yǔ băo guó, 272.

${ }^{49}$ Dade is the second period of the era of Temür Khan- Cheng Zong (成宗) (1294-1307). His reign is divided in two periods; the first is the period of Yuanzhen (元貞), the second period is Dade (大德). Dade lasted 11 years starting from the year 1297 and ending in 1307. See Taozi, Liăng sòng yuán, 82; Chen, Jiănpǔzhài shǔ, 59; Fanyong, Shì dà yǔ băo guó, 272.

${ }^{50}$ Marshallsay, "Between The State", 2.

${ }^{51}$ Israeli, "Islam in China", 254.

${ }^{52}$ Schirokauer, A Brief History, 221.

${ }^{53}$ Wahby, Islamic Architecture in China, 30.

54 Sayyid Ajall Shams al-Din Omar al-Bukhari (سيد أجل شمس الدين عمر) (1211-1279) comes from Bukhara in Central Asia (now Uzbekistan). When the Mongols conquered Khwarizm, his tribe surrendered to them. Later, his father served in the Mongol army. Sayyid Ajall was the ruling elite of the Mongol state. In 1220 he served in the Mughal political system and became a military commander of the Mongols. He held many leadership positions in the Yuan Dynasty. In 1274, he became the governor of Yunnan Province. Shams al-Din Omar had many great architectural contributions; he ordered the construction of Buddhist and Confucian temples as well as mosques. See Vissière, "Le Seyyid Edjell", 330-346; Daryaee, The Oxford Handbook, 252; Needham, Science and Civilisation, 297; Wang, "Yuán dài yúnnán jiàoyù kăo", 1-8; Lane, "The Dali Stele", 1-39; Broomhall, Islam in China, 127; Gaubatz, Beyond the Great Wall, 78; Rossabi, Eurasian Influences, 64; Chenxue, "Míngdài huànguān", 173.
} 
The inscription gave us the ancient name of the mosque, Qingjing Mosque, which derived its name from the street of Qingjing. The text also draws our attention to the mosque's two architectural phases during the Yuan dynasty; the first in 1263 during the Kublai Khan's reign (1260-1294), the second in 1297 during the reign of Temur Khan-Cheng Zong (成宗) (1294-1307). According to the text, the last architectural improvements before Ming dynasty were made by Sayyid Ajall Shams al-Din Omar. However, it is historically known that he died in 1279 in Yunnan; ${ }^{55}$ in addition he did not serve in Shaanxi, but was appointed Director of Political Affairs of the Regional Secretarial Council of Yunnan. ${ }^{56}$ The inscription is therefore of great importance, as it gives a new political position occupied by Shams al-Din Omar and not mentioned in the Ming official historical texts.

\title{
[5] THE FOURTH MARITIME JOURNEY
}

\begin{abstract}
“及我國朝永樂十一年四月太監鄭和奉敕差往西域天方國道出陝 西求所以通譯國語可佐信使者乃得本寺掌教哈三焉乃於是奏之朝 同往卒之揄揚威德西夷震壟及回斾海中風濤橫作幾至危險乃哈三 籲天留賏默禱於教宗馬聖人者已而風恬波寂安妥得濟遂發洪誓重 修所謂清淨寺者”

“During the Ming Period, the eunuch Zheng He (鄭和) led the naval fleet to the Arab countries [or Mecca] (天方國) in the west. In [1413] the fourth month of the eleventh year of Emperor Yongle reign (永樂) (1402-1424), ${ }^{57}$ Zheng He made a personal visit to Shaanxi Province, with the focus of finding a reliable assistant interpreter for his voyage. One of the trusted men was found in the mosque, he recruited Hassan (哈三) the Imam of the Mosque who played an important role at the Ming court, and served them as a soldier. He has got a lot of prestige and praise; because of his mission in the Western countries. On the way back to the homeland [China], when the fleet was caught in a great storm and was exposed to many dangers, Zheng He rushed for help from Hassan and asked him to pray in order to provide divine protection to all his crew. Hassan stayed in the cabin and devoted himself to pray; suddenly the wind and waves calmed down and everyone were safe thanks to him. This prompted him to vow for the reconstruction of the mosque, which is known as the Qingjing Mosque, 清淨寺.”
\end{abstract}

The text describes a historical event during Yongle's reign (1402-1424), the fourth maritime voyage of Zheng He, ${ }^{58}$ the voyage to the Tianfang country. The term of Tianfangguo (天房

\footnotetext{
${ }^{55}$ Chang, "Cóng `fān kè'dào ‘huízú'”, 309-318; Rossabi, From Yuan to Modern China, 279.

${ }^{56}$ Mann, Cheng, Under Confucian Eyes, 86.

${ }^{57}$ The Yongle Emperor (永樂), also known as Chengzu (成祖) and Zhu Di (朱棣), was the third Emperor of the Ming dynasty, his reign extending from 1402 to 1424 . He was the son of the Hongwu Emperor (洪武) (r. 13681398), the founder of the dynasty. He took the power after his predecessor the Emperor Jianwen (建文) (r. 13981402). See Brook, The Confusions of Pleasure, 34-75; Watt, Leidy, Defining Yongle.

${ }^{58}$ Zheng He is one of the most famous Chinese Muslim leaders and greatest navigators from China. He was born during the Ming Dynasty in 1371 and died between 1433-1435. He was the son of a Chinese Muslim family of Yunnan Province. Between 1405 -1433, Zheng He commanded seven expeditionary voyages to Southeast Asia, Western Asia, and East Africa. See Church, "Zheng He", 1-43; Duyvendak, "The True”, 341 -
}

- 142 - DOI: $10.36816 /$ shedet.006.08 
國-天方國), literally means "the land of the heavenly arena", which refer to the Ka'ba in Mecca, ${ }^{59}$ was the Chinese term in the Middle Ages for the Arabian Peninsula. Most historians believe that the term refers only to Mecca, ${ }^{60}$ while others believe it indicates the Arabian Peninsula as a whole. ${ }^{61}$ In the Ming period, the term of Tianfangguo was used instead of the term of Dashiguo (大食國), which was common in the historical records of the Tang Dynasty. ${ }^{62}$ The event dates back to the eleventh month of the 10th year of reign of Emperor Yongle. $^{63}$

On 18 December 1412, the Yongle Emperor issued the order to Zheng He to prepare for the fourth voyage. ${ }^{64}$ Zheng He carefully planned the trip to make it a success, as it was the first attempt to open a new route across the Indian Ocean to reach the East African coast of Arab countries and regions. ${ }^{65}$ Zheng He focused on finding a reliable interpreter to be a messenger on his journey. ${ }^{66}$ The desired man for Zheng He must have experience in the traditions of the Arab regions, culture and geography and able to communicate with them, and thus known excellent Arabic.

The inscription recorded that, in 1413, the 4th month of the 11th year of Yongle reign, Admiral Zheng He was in Xi'an to seek reliable interpreters and found a reliable man named Hassan (哈三). ${ }^{67}$ In parallel, he would be effective in communicating with Islamic countries in order to facilitate dealing and negotiation with them. He also acted as religious counsellor to meet the daily life needs of the Muslims crew, such as Imamah prayers, as well as funeral prayers and Islamic slaughter rituals. ${ }^{68}$ Hassan also made several pilgrimages to Mecca, and his experience of sailing lanes, which made him worthy of the reliable navigator for the Zheng He fleet; so he accompanied him on his voyage. ${ }^{69}$

In autumn 1413, the fleet left Nanjing ${ }^{70}$ and navigated towards the western countries. Zheng He proceeded to India and Hormuz, a battalion of the fleet cruised southward down the southern coast of Arabian Peninsula, arrived in Dhofar, Aden, Tianfang (Mecca), and Egypt. ${ }^{71}$ On 12 August 1415, Admiral Zheng He's fleet returned to Nanjing. ${ }^{72}$ However, the inscription states that when the voyage sailed on the way back, Zheng He rushed to seek help from Hassan, حسن, to pray for the divine protection of all his crew; Hassan's prayers yielded good results as suddenly the storm calmed down, and the crew survived. Zheng He's appreciation of Hassan was a reason for the reconstruction of the Qingjing mosque, implying that the reconstruction of the mosque was a result of this event.

413; Peterson, "The Ming Voyages", 43-51; Dreyer, Zheng He; Graff, "Zheng He", 213-214; Yangwen, "Shìqù de zhēnshí", 42-45; Chenxue, "Míngdài huànguān", 163-192.

${ }^{59}$ Rockhill, "Notes on the Relations and Trade", 620; Pelliot, Paul, "Les grands voyages", 237-452.

${ }^{60}$ Xin, "Zhèng hé”, 66; Zhang, "Xià xīyáng”, 69; Kenzheakhmet, Nurlan, "The Place Names of Euro-Africa”, 109.

${ }^{61}$ Chenxue, "Míngdài huànguān", 173; Nappi, The Monkey and the Inkpot, 36; Zheng, Zhènghé quán chuán, 261.

${ }^{62}$ Houjin, Jiutang shu; Songouyang, Xintang shu.

${ }^{63}$ Yanghuai, Zhèng hé, 140.

${ }^{64}$ Dreyer, Zheng He, 75.

${ }^{65}$ Hoon, Zheng He's Art of Collaboration, 254.

${ }^{66}$ Terada, Zhèng hé, 79.

${ }^{67}$ Levathes, When China Ruled the Seas, 138

${ }^{68}$ Yanghuai, Zhèng hé, 101; Hoon, Zheng He's Art of Collaboration, 254.

${ }^{69}$ Zheng, Hao, Fènghuáng, 45.

${ }^{70}$ Dreyer, Zheng He, 76.

${ }^{71}$ Pletcher, The Britannica Guide, 47; Friedman, Routledge Revivals, 440.

${ }^{72}$ Dreyer, Zheng He, 81. 


\section{[6] THE ARCHITECTURE OF MING}

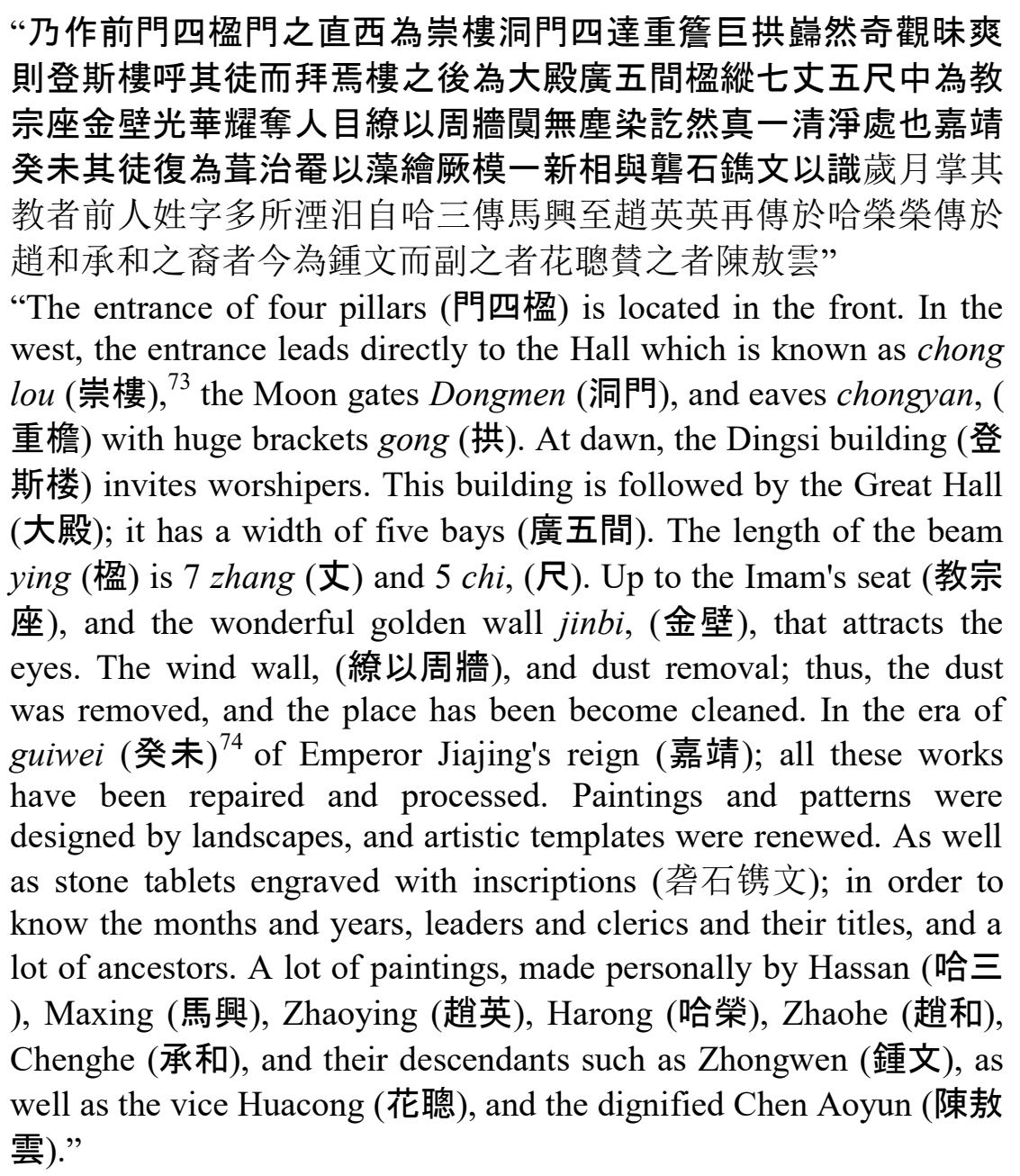

The Jiajing Stele is an important record of mosque's architecture during Ming period, and as the description is accurate for the architectural works that were added to the mosque during Emperor Yongle's reign by Admiral Zheng He. It is worth mentioning that the recording of the description of these works was made in an orderly and sequential manner. All elements and architectural units were mentioned from the facade of the mosque in the east in a regular sequence to the prayer area in the West. The text then dealt with the restoration of paintings, and mentions the prayer hall including the measurement with units common in the Ming era. The length of the Prayer Hall's facade dadian (大殿) was reported, 7 Zhang and 5 Chi (七丈 五尺). Chi is a Chinese measuring unit based on the human hand, equal to $33.3 \mathrm{~cm} ;{ }^{75}$ Zhang (丈) is a Chinese measurement unit equal to $10 \mathrm{Chi}$ (10 尺) ${ }^{76}$ the total length of the facade is

\footnotetext{
${ }^{73}$ The term of Chongluo structure (崇樓) literally means "layered houses, multistoried tower, or storied building”. It is equal to both of Chongluo (重樓), and Chongceng (重層). See Sze, Stupas in medieval China, 109. ${ }^{74}$ The era of guiwei corresponds to the year $1523 \mathrm{AD}$; it is the second year of the reign of Jia Jing (1522-1566). See Zhouchun, Sòng yuán míng qīng, 242; Liushu, Rújiā zhéxué, 199.

${ }^{75}$ Daiwu, Hànzì zhōng de gǔdài kējì, 187; Wang, Xīyù kăochá yǔ yánjiū, 397; Lu, A History of Chinese Science, 180.

${ }^{76}$ Yao, Nanjing, 18; Ioannides, "Walled cities”, 71-88; Liuguo, Zhōngguó gōngyè shĭ, 680; Nujiang, Nùjiāng zhōu nóng mù zhì, 492.
}

- 144 - DOI: $10.36816 /$ shedet.006.08 
24.75 metres. As these are the current dimensions, the current architecture of the prayer hall dates to the Ming period. ${ }^{77}$ However; this inscription is important as it is a rare example both in China and in the Muslim world that included specific dimensions of the prayer space.

The following are the architectural units and elements of the mosque, which were recorded in the inscription:

1- 崇樓: chonglou. The term of Chongluo structure (崇樓) literally means layered houses. It is equal to chongluo (重樓), and chongceng (重層). ${ }^{78}$

2- 洞門: dongmen. The term of dongmen (洞門) literally means "tunnel portal”, but it is often used to refer to the Moon gates yueliangmen (月亮門). ${ }^{79}$

3- 登斯楼: ding si lou. The term of dengsiluo (登斯樓) may indicate the minaret. The minaret in Chinese mosques has many names, such as xuan li ta (宣禮塔), the most widely used term in China, as well as the bangke lou (邦克樓), huan xing lou (喚醒樓), huan bai lou (喚拜樓), and wang ta (望塔).

4- 大殿: da dian. The great hall refers to the prayer hall and is always located on the western side of the mosque and extends from east to west in the direction of the Qibla.

5- 教宗座: jiaozong zuo, is the pulpit (Arabic: Minbar "منبر"); it is known by many terms such as minbaier (敏拜爾), jiang jing tai (講經台), and xuan jiang tai (宣講台). ${ }^{80}$

6- 金壁: jinbei, I assume this term is meant to be the qibla wall that contains the niche of the Mihrab. There are many terms for the Qibla wall, such as Mihalabu (米哈拉布) which was derived from the Arabic word (محراب), aobi (凹壁), As well as Shang kan (圣 龛). ${ }^{81}$

7- 繚以周牆: liao yi zhouqiang. The wind wall is the external wall that surrounds the architectural unit of the mosque.

\section{[7] THE DATING FORMULA}

“大明嘉靖式年歲次癸未秋九月吉日立.長安葉文舉刻”

"Ming Dynasty, set up on an auspicious day of the ninth month of autumn of the year of Guiwei (癸未), the second year of Emperor Jiajing's reign. Chang'an (長安). Yuwen Juke (葉文舉刻).”

The dating formula of the inscription is a standard complete version, which includes six components: "the ruling dynasty of China, the Emperor's name, the Emperor's period, the era, the month, and the day". The transliteration of the inscription follows Da Ming Jiajing er nian suici guiwei jiuyue ji rili, "Great Ming, Jiajing (1521-1567), ninth month, (the year of Guiwei) the second year", dating to January 1523.

\section{WAS THE MING COURT A PATRON FOR CHINESE MOSQUES?}

According to Chinese Muslim historiography, some Ming Dynasty emperors were Muslims such as Emperor Zhu Yuanzhang. Chinese Muslims Historians believe that he converted to

\footnotetext{
${ }^{77}$ Hagras, “Xi'an Daxuexi Alley Mosque”, 97-113.

${ }^{78}$ Sze, Stupas in medieval China, 109.

${ }^{79}$ Yanghong, Zhōngguó jiāngnán, 76; Wangqi, Zhōngguó yuánlín, 196.

${ }^{80}$ Fan, "Zhōngguó liăng lèi qīngzhēnsì", 221-225; Tong, Běijīng zōngjiào, 187.

${ }^{81}$ Liuwei, Níngxià huízú, 67; Lujin, Yīlăng, 294; Caiyan, Zhōngguó jiànzhú, 82.
} 
Islam. ${ }^{82}$ The True Explanation of the Right Religion, 正統的新詮, was the first major classic Chinese Islamic work, published in 1642 by the Muslim historian and theologian, Wang Daiyu, 王袋輿, (1580-1658) $)^{83}$, quoting “In the first year [of Hong Wu's reign] the emperor called for the construction of a mosque in Jingling and wrote the Baizizan, 百字讃, 'hundred Character praise,' praising Islam”. ${ }^{44}$ Another Muslim historian, Liu Zhi (刘智) (1660-1730) in his book the Veritable Records of Islam's Prophet (天方至圣实录) referred to Hong Wu's relationship with Muslims, saying "Nowadays, the emperor esteems the Huihui [Muslims]; the founder of the Ming Dynasty appreciated the learning of Islam" ${ }^{85}$ This hypothesis has been supported by many contemporary Muslim historians. ${ }^{86}$ According to Chinese Muslim tradition the first wife of Zhu Yuanzhang, Empress Ma Hou, was a Muslim; he also had an adoptive Muslim son Mu Ying, 沐英. ${ }^{87}$

Current scholars have denied this religious conversion of Ming emperors; their support for this negation is that this picture is extremely different from official Ming histories and nonMuslim sources. Conventional histories such as the Official History of the Ming Dynasty Ming shi (明史) or the Veritable Records of the Ming Dynasty Ming shilu (明实录) lend little support to such claims. ${ }^{88}$ We should take into consideration that Hong Wu had a strong relationship with the Muslims; he had ten Muslim Generals in his army, ${ }^{89}$ adoptive Muslim kin, a Muslim wife, favourable policies towards Islam, and relies on the Muslim leader Zheng He and mandates him to sail to the West [Islamic world]. These factors attest to the emperor's "intimate relationship" with the Chinese Muslims. ${ }^{90}$ In 1368, Hong Wu wrote the "One Hundred Words of Praise"," which is known to Chinese Muslims as the Baizi zan, 百 字讃, literally means The Hundred-word Eulogy, ${ }^{92}$ to praising Islam and prophet, ${ }^{93}$ erected in Nanjing Mosque. The Dongsi Mosque in Beijing also contains a tablet erected in 1569, during the era of Emperor Wanli (1572-1620), containing part of this poem. ${ }^{94}$ In 1392 , Zhu Yanzhang called for the establishment of several mosques; ${ }^{95}$ during his period large numbers of Muslim family moved to his capital Nanjing. ${ }^{96}$

At the resumption of the Yuan era, Chinese Muslims had emerged as an important social class in China. Numerous accounts of travellers who visited China during the Ming period testify to their wellbeing. One example is that of the Ottoman geographer Ali Akbar Khata'i

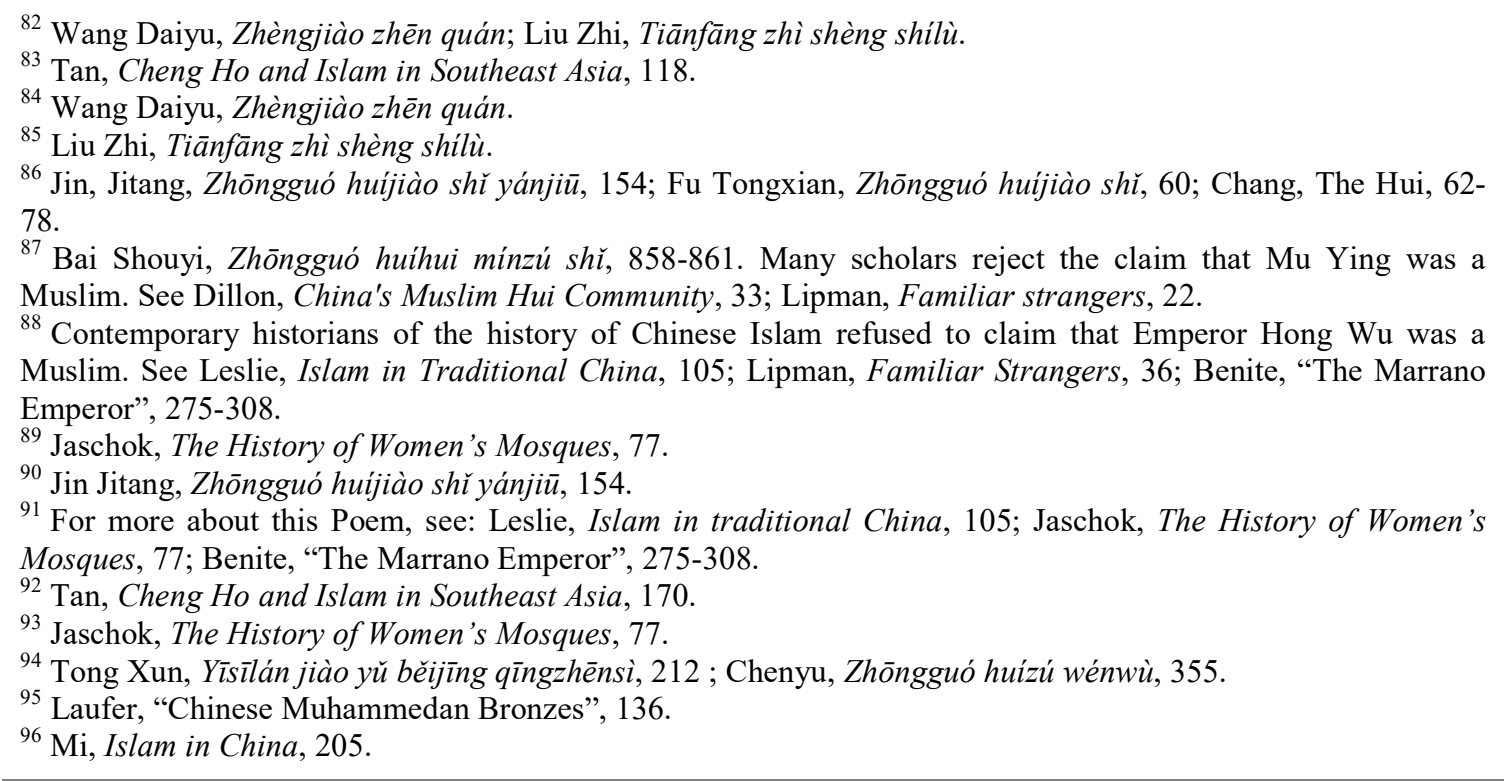

- 146 - DOI: $10.36816 /$ shedet.006.08 
who visited China in 1505-1506. In his book The Khataynameh (The Book of China), Khata'i in which he reported that "the Emperor [Xiaozong- Hongzhi Emperor (1487-1505)] not only employed many Muslim officials but also had a marked personal inclination toward Islam ...., The Kin Tay (Zhengde, r. 1505-1521) had been very friendly with the Muslims and had Muslim warlords under his service....., the eunuchs of the Chinese palace are all Muslims who can practice their faith without any limitations. The son of Kin Tay Khan converted to Islam after seeing Muhammad in his dream and finding the shahada inscribed on his wall in green letters". 97

\subsection{WHY WAS THE MING COURT A PATRON OF MOSQUES?}

It is noteworthy that Chinese Muslims lived their golden age during the Mongol era and spread their communities throughout the country thanks to the large migrations of Muslims, in addition to the political and economic advantages they obtained. ${ }^{98}$ This status was confirmed by travellers who visited China during the Mongol period, such as the Italian explorer, Marco Polo (d. 1324), who is referring to many Muslim enclaves in northern China. ${ }^{99}$ The Arab traveller Ibn Battuta (d. 1377) referred to Muslim communities: "In every city of China, there is an exclusive city [enclaves] of Muslims, and have mosques". ${ }^{100}$ The contemporary historians such as Liuzhi Ping estimated the number of Chinese Muslims in 1263, during the fourth year of the reign of Kublai Khan (1260-1294), to the equivalent of $10 \%$ of the Chinese census, ${ }^{101}$ while at the end of the Yuan Dynasty (1271-1368) the numbers reached four million people according to Israeli. ${ }^{102}$

With the Yuan-Ming transition, some restrictions were imposed on Muslims' travels. This resulted in prohibiting contacts with neighbouring Muslim communities in Central Asia, ${ }^{103}$ and Chinese Muslims became completely isolated. ${ }^{104}$ So they have been looking for funding for mosques to ensure the continuity of its functions throughout the ages to meet the demands of the Islamic community and accomplish its objectives. The waqf [endowment] was known during the Yuan Dynasty; historical sources contained allusions to the waqf during that era; Ibn Battuta (d. 1377) tells about Muslims in the city of Khansa-Hangzhou, in which he reported that "There are great numbers of Muslims... They have a Zāwiya [institution] known as al- Uthmaniah that has a good architecture, many waqf, and a number of Sufis. Uthman built the mosque in this city. He makes for each of the mosque and Zawiya many waqfs". ${ }^{105}$ We can conclude from words of Ibn Battuta that the system of waqf of mosques was in force during the Mongol era. But it only spread significantly in the late Ming Dynasty (1368-1644) and early Qing Dynasty (1644-1912) ${ }^{106}$ during which Muslims began buying lands and properties, and established a waqf for mosques. ${ }^{107}$

\footnotetext{
${ }^{97}$ Laufer, "Chinese Muhammedan Bronzes", 135; Emiralioğlu, "China and the Ottoman Imperial Project”, 161 187.

${ }^{98}$ Marshallsay, "Between the State and Islam", 2.

${ }^{99}$ Liuzhi, Zhōngguó yīsīlán jiào jiànzhú, 7.

${ }^{100}$ Ibn Battuta, Tuhfat al-Nužzāer, 628.

${ }^{101}$ Liuzhi Ping, Zhōngguó yīsīlán jiào jiànzhú, 6.

${ }^{102}$ Israeli, Islam in China, 255.

${ }^{103}$ Marshallsay, "Between the State and Islam", 3.

${ }^{104}$ Israeli, Muslims in China, 83.

${ }^{105}$ Ibn Battuta, Tuhfat an-Nuzzāer, 638.

${ }^{106}$ Li-hua Ying, Almasajid fi al-Sin, 78.

${ }^{107}$ Hagras, Almasajid al'athariat, 41-42.
} 
However; the Ming court was anxiously monitoring the Muslim communities, which certainly had been growing in great numbers over time; the court's policy was thus aimed at attracting them and trying to assimilate them to ensure their loyalty and not to threaten its powers and feudal policy. The growing number of Muslim communities in China has led to the urgent need for new mosques. The Ming emperors found a favourable opportunity to attract Muslims towards them and force them to feel that they are in one of the countries of the Islamic world, which cares about religious architecture and includes them.

It seems that the Ming's policy with the Muslims was intended to facilitate the connection of the court to the neighbouring Islamic world. The Muslims were the ablest to communicate with the embassies of the Islamic world; this is due to their mastery of the dominant language in the Islamic world, namely Arabic and Persian languages such as the Muslim eunuch Mawlana Haji Yusuf al-Qadi, who received the Embassy of Shah Rakh (1405-1447) to Beijing between 1419 -1422 during Yongle's reign (1402-1424). ${ }^{108}$ Many embassies were assigned to the Muslim sailor Zheng He to visit the Arab and Muslim world in the West. In his third voyage (1412-1415) Zheng He visited several cities such as Dhofar, Aden, and Mecca in the Arabian Peninsula ${ }^{109}$ as well as the East coast of Africa, ${ }^{110}$ and returned to visit the region again on his seventh maritime voyage in 1430-1433, during which he sent a messenger to the rulers of Mecca with gifts. The Ming court received embassies from Arabia and Muslim Lands, leading the embassies' members' number to increase drastically, to the extent that in the $1470 \mathrm{~s}$, the Chinese court ceremony officials objected to such growth. ${ }^{111}$

The Ming emperors not only issued the decrees of constructing and renovating the mosques but also gave to Muslim families grants in kind of dibs, fabrics, etc. according to the inscription, which was erected in 1405 during the Yongle Reign. In 1392, Sai Hazhi, 賽哈智, a Muslim personage, had an audience with Yongle; the Emperor granted him a decree permitting the construction of two mosques, one in Chang' an (Xi'an), and one in Nanjing: "He [Sai Hazhi] obtained an audience with the emperor and was granted the following decree- - 'fifty ingots silver and two hundred pieces of cotton cloth be given to each Huihui [Muslim] family",. ${ }^{112}$

There are many historical shreds of evidence indicating the contribution of emperors for the establishment and repairs of Chinese mosques in various provinces. Muslims in Nanjing inherit the story of Yongle and Nanjing mosque as a kind of appreciation and affection for Muslims; thus he was accompanied by the two Muslim ministers, Chang Yuchun and $\mathrm{Hu}$ Dahai; the Emperor visited the old mosque in Nanjing, and got off his sedan chair and entered the courtyard, walking straight toward the great hall [Prayer hall]. One of his feet had stepped into the hall before Chang Yuchun was able to stop him and say, "Your Majesty, the rules of Islam require us to take off our shoes before entering." Zhu Yuanzhang looked as if awakening from a dream, and he said, "ayah-I did not know the custom." Then he drew back his foot and ordered, "Come! Dig out the footprint I have just made on the floor!" after

\footnotetext{
${ }^{108}$ Laufer, "Chinese Muhammedan Bronzes", 135.

${ }^{109}$ Levathes, When China Ruled the Seas, 61-62; Dreyer, Zheng He, 11.

${ }^{110}$ Zai Suo, Ming zhènghé zhī yánjīu, 130-40; Zhang Tingyu, Míngshĭ, 7766; Zaichen, Zhènghé, 21-40; Jianai, Zhōng fềi guānxì, 165.

${ }^{111}$ Bretschneider, Mediaeval researches, 289; Rossabi, "Muslim and Central Asian Revolts", 169-199; Wahby, Islamic Architecture in China, 47.

${ }^{112}$ For a photo of the inscription and an English translation, see Broomhall, Islam in China, 91-92.
}

- 148 - DOI: $10.36816 /$ shedet.006.08 
he went back to the palace and sent his men to have the footprint inlaid with gold. Therefore, this mosque became known as the "Golden Foot Mosque". ${ }^{113}$

The Chinese Muslim historian, Ma Zhou 马注 (1640-1711), in The compass or guide to Islam (清真指南), indicates the auspices of Ming court with local Muslims and their mosques; he stated in the preface "In the spring of the twenty-fourth year of the Hong Wu's reign [1391], the emperor ordered my ancestor Sai Hazhi [賽哈智] of Xianning to renovate facilities for ritual washing and mosques in Chang'an [Xi'an], Nanjing and elsewhere". ${ }^{114}$ The stele of Sai Hazhi which was erected in 1405 in Xi'an Grand Mosque, stated that Sai Hazhi had an audience with Yongle Emperor in 1392, and was granted a decree permitting the building of two mosques, one in Xi'an, and one in Nanjing "two mosques to be built in two places, one in the Tongzuo- fang, Sanshan Street in the prefecture of Yingtian, Nanjing; and one in Ziwu street, in Chang'an county, Xi'an prefecture, Shaanxi. If a mosque falls into decay, it may be repaired without delay." The Yongle Emperor followed his father's policy towards Muslims and walked on his path; he issued decrees to build mosques in Xi'an, Beijing, and Nanjing. ${ }^{115}$

Ming's auspices of the mosques did not stop at this point, but the court recognised the mosques and gave them official status. Ming court has given some of the mosques in the new capital Beijing, the official status and government recognition of this kind of religious architecture in recognition of the Muslim military men, as a realistic result in exchange for their assistance and standing alongside emperors and fighting in their forces against rebellions and revolutions. ${ }^{116}$ The official mosques in Beijing were granted the name of Sidaguansi, 四大官寺, ${ }^{117}$ the four official mosques. This is a logical and predictable result of the pragmatic policy adopted by the Chinese government in dealing with the political interests imposed by the surrounding circumstances as well as the turmoil experienced by the emperors. . Contributed to these situations, Chinese Muslims have helped the emperors to confront these disturbances, and have thus been given ample attention and prestige at the court.

Financial support for the construction of mosques was provided in more than one city; many mosques across China received this kind of government support, such as the Beijing Niujie Mosque, which had a financial grant from Emperor Cheng Hua in $1474,{ }^{118}$ and the Beijing Dongsi mosque, which Emperor Jingtai contributed to the renovation and repair works, ${ }^{119}$ as well as Nanjing mosque, which was built by Emperor Yongle to encourage Zheng He to sail in the Indian Ocean. ${ }^{120}$ In 1505-1506, Ali Akbar reported that "The Chinese emperor [Hongzhi, r. 1487-1505] in Khanbaliq [Beijing] built four mosques for Muslims". ${ }^{121}$ It seems that Ali Akbar reported that the contribution of Emperors to finance the construction of

\footnotetext{
${ }^{113}$ The English version of this tale is in Li, Mythology and Folklore, 235; Wu Jianwei, Zhōngguó qīngzhēnsi, 128-129; Benite, "The Marrano Emperor", 275.

${ }^{114}$ Ma Zhu, qīngzhēn zhǐnán, 11; Benite, "The Marrano Emperor”, 285.

${ }^{115}$ Gladney, Muslim Chinese, 269; China, China archaeology, 29.

116 Tong Xun, Yīsīlán jiào yǔ běijīng qīngzhēnsì, 140; Liuzhi, Zhōngguó yīsīlánjiào, 89.

${ }^{117}$ The Beijing's four official mosques (Sidaguansi), 四大官寺, are Niujie Mosque (牛街礼拜寺), Dongsi Mosque (东四清真寺), Pushou Mosque (锦什坊街谱寿寺), and Faming Mosque (法明寺). See Tang Zongzheng, “Běijīng shì qīngzhēnsì", 41-43.

${ }^{118}$ Lu Bingjie, Zhōngguó jiànzhú, 12.

${ }^{119}$ Chenyu, Zhōngguó huízú wénwù, 29; Tong Xun, Yīsīlán jiào yǔ běijīng, 215-216.

${ }^{120}$ Hua Ying, Almasajid fi al-Sin, 72.

${ }^{121}$ Ding Hui-Qian, "Míng qīng běijīnng chéngqū", 32-36.
} 
mosques throughout the Ming period, which is a continuation of the rules and policies, set by the founder of the Ming Dynasty.

As for the Jiajing stele in the Daxuexi Mosque - the present case study - its condition is consistent with the policy of the Ming court. Anyway, the Ming court financed successive architectural and reforms of the mosque during this dynasty. Admiral Zheng He was greatly admired and appreciated by the Xi'an Muslim community for obtaining an imperial decree to rebuild the mosque, and also for his fulfillment and promise to Hussein, the imam of the mosque. In addition, the emperors adopted a pragmatic policy towards Chinese Muslims. They helped finance the construction operations of the mosque as a reward to Zheng He and Hassan, who were able to make a successful maritime voyage to the Islamic world and were able to establish relations with the Arab region. We should also bear in mind that later, the Ming court continued to communicate with the Muslim world relying on Zheng He and Muslims. It can be asserted that the architectural works of the Daxuexi Mosque were a logical consequence of Chinese's journeys under the leadership of Chinese Muslims during the Ming Dynasty to the Muslim world.

\section{CONCLUSIONS}

The Jiajing Stele was erected in 1523 during the Jiajing reign a hundred years after the fourth maritime voyage of Zheng He. The reconstruction of the Mosque was by Zheng He who financed the reconstruction process after successfully obtaining imperial funding, he made a comprehensive overhaul of the mosque as a reward for the dedication of Hassan, one of the clerics of the mosque. The inscription clearly indicates that the Chinese Muslim leaders during the Ming period built mosques; they were sponsors of Islamic art and architecture of China. Different from its current name, Daxuexixiang Mosque, the text provided us with the earliest name of the mosque, the Qingjing Mosque, 清淨寺, which confirms the historical evolution of the names of the mosque. ${ }^{122}$ The term of qingjingsi (清淨寺) consists of three Chinese characters: qing (清) (clean or pure), zhen (真) (the truth), and si (寺) (the temple). Chinese Muslims used the word of qingjing 清淨 (clarity and purity); ${ }^{123}$ this word is widely used in China to refer to everything that is Islamic.

The Jiajing Stele celebrates Sayyid Ajall Shams al-Din Omar the most famous historical figures of the Chinese Muslims of the Yuan Dynasty, as well as Hassan's success in his mission during on the fourth maritime voyage of Admiral Zheng He, when he received appreciation and praise by the Yongle's court. The Stele is a testament to the success that the leaders of Chinese Muslims enjoyed. The significance of the Jiajing Stele is that it showed an attitude in the policies of the Ming court towards Muslims community and a deeper awareness of methods of the fostering of loyalty. The Jiajing Stele is an important historical record that has captured part of the history of Chinese Muslims, how the earliest Islamic communities were formed in Xi'an; it has devoted considerable space to recording the biography of two of the most famous figures in the history of China: Sayyid Ajall Shams alDin Omar of the Yuan period, and Zheng He of the Ming period. This is seen as an early attempt by Chinese Muslims to document their own history.

\footnotetext{
${ }^{122}$ For the historical evolution of Chinese Mosques. See Hagras, Almasajid al'athariat, 33-34; Hagras, "An Ancient Mosque in Ningbo," 102-113.

${ }^{123}$ Bloom, The Grove Encyclopedia of Islamic Art, 483- 485.
}

- 150 - DOI: $10.36816 /$ shedet.006.08 
The text also clearly highlighted the evolution of the Chinese names of the Arabian Peninsula. The name of this region in the text is "Tianfang country-lands" (天方國) which is the Chinese name during the Ming period, while the same region was known to the Chinese during the Tang Dynasty as "Dashi country-lands" (大食國). The inscription combines the construction of the mosque since the Tang dynasty to the Ming dynasty, and also recites a precise description of the mosque's architecture, which confirms that the mosque in its present composition and structure is due to the innovations of Zheng He. The current dimensions of the prayer hall of the mosque are the same as those mentioned in the text which supports the statement that the inscription is an important document containing a precise description of the mosque's architecture in a historical sequence since the Tang period until the reign of Emperor Jiajing of the Ming Dynasty. The text also includes many architectural terms of the units and elements of the mosque, which sheds light on the evolution of these terms through the ages.

The inscription is an important historical document that effectively monitors the relationship between Ming and Muslims. The text addressed the political relations between Ming and the Western world (the Islamic world). In addition to notarizing the status of Chinese Muslims during the Ming period and the emergence of an important social class in the social pyramid such as navigator Zheng He, the text also highlighted the political pragmatism of the Ming's court and its attempt to attract, contain and care for Muslims through the funding of the construction and renovation of mosques. The architectural works of the Daxuexi Mosque were a logical consequence of Chinese journeys under the leadership of Chinese Muslims during the Ming Dynasty to the Muslim world in the West. 


\section{REFERENCES}

- Adam (Yuen-Chung), "The Practical Training of Government Officials under the Early Ch'ing, 1644- 1795”, Asia Minor 16 (1971), 82-95.

- Adshead (S. A. M.), T'ang China: The Rise of the East in World History, New York, 2004.

- Arnaiz (Greg), Van Berchem (Max), "Memoires sur les Antiquites Musulmanes de Ts'iuantcheou", T'oung Pao, serie 2, VI, E.G., BRILL (1911), 677-727.

- Bai Shouyi, Zhōngguó huíhui mínzú shǐ (A History of the Chines Hui People), Zhonghua Book Company, 2007.

- Ben She, Yīsīlán jiào jiànzhú zhī, yīsīlán jiào jiànzhú, mùsīlín lìbài qūngzhēnsì (Islamic Architecture, Mosques), Beijing: Zhongguo Jianzhu Gongye Press, 2009.

- Benite (Aziz Ben-Dor), "Even unto China, Displacement and Chinese Muslims Myths of Origin", Bulletin of The Royal Institute for Inter: Faith Studies 4 (2002), No. 2, 93-114.

- Benite (Aziz Ben-Dor), "Follow The White Camel, Islam in China to 1800", New Cambridge History of Islam, 4 (2010), 409-426.

- Benite (Aziz Ben-Dor), "The Marrano Emperor, The Mysterious, Intimate, Bond between Zhu Yuan zhang and his Muslims", in Sarah Schneewind, Long Live The Emperor: Uses of Ming Founder Across Six Centuries of East Asian History, Ming Studies research Series, 2008, No.4, pp. 275-308.

- Bloom (Jonathan), Blair (Sheila), The Grove Encyclopedia of Islamic Art and Architecture, Volume 2, Oxford University Press, 2009.

- Bowman (Alan), Trade, Commerce, and the State in the Roman World, Oxford University Press, 2018.

- Bretschneider (Emil), Mediaeval Researches from Eastern Asiatic sources, London, 1967.

- Brook (Timothy), The Confusions of Pleasure, Commerce and Culture in Ming China, Berkeley: California University Press, 1999.

- Broomhall (MarsHall), Islam in China: A Neglected Problem, Morgan, Scott, Limited, 1910.

- Caiyan Xin, lu Bingjie, Zhōngguó jiànzhú yishù (Art of Chinese Architecture), Zhongxin Press, 2006.

- Chang (Hajji Yusuf), “The Hui (Muslim) Minority in China, an Historical Overview”, Journal of The Institute of Muslim Minority Affairs, 8 (1987), No.1, 62-78.

- Chen Hongyu, Jiănpǔzhài shř (History of Cambodia), Dulizuojia, 2015.

- Chen Ruilin, Zhōngguó gŭdài túxíng yishù̀ jiăn shǔ (A Brief History of Graphic Arts of Ancient China), Qinghua University Press, 2006.

- Cheng (Joseph), the Use of Mao and the Chongqing Model, City University of HK Press, 2015.

- Chenxue Lin, "Míngdài huànguān yŭ zhènghé xià xīyáng de guānxì" (the Ming Dynasty's eunuchs and Relations of Zheng He's Voyages), Zhōngguó wénhuà yánjiū suǒ xuébào, 48 (2008), 163192.

- Chenyu Ning, Tang Xiao fang, Zhōngguó huízú wénwù (Heritage of Chinese Hui Minority), Ningxia Renmin Press, 2007.

- China, China archaeology and art digest, Volume 3, Issue 4, Art Text (HK) Ltd. 2000.

- Chongmei Guo, "Jiāxìng fǔ jiàn zhēnjiào sì bēijì--chūtàn" (Study on Inscriptions of Zhenjiaosi Mosque in Jiaxing City), Zhōngguó Mùsīlín, 2 (1991), 29-30.

- Church (Sally), "Zheng He: An investigation into the plausibility of 450-ft treasure ships", Monumenta Serica: Journal of Oriental Studies, LIII, (2005), 1-43.

- Clark (Hugh), Portrait of a Community: Society, Culture, and the Structures of Kinship in the Mulan River Valley (Fujian) from the Late Tang Through the Song, Chinese University Press, 2007.

- Clements (Jonathan), A Brief History of Khubilai Khan, Philadelphia: Running Press, 2010.

- Crespigny (Rafe), Fire over Luoyang: A History of the Later Han Dynasty 23-220 AD, Brill, 2016.

- Daiwu San, Hànzì zhōng de gŭdài kējì (Ancient Science and Technology of Chinese Characters), Baihua Wenyi Press, 2004. 
- Dardess (John), A Political Life in Ming China: A Grand Secretary and His Times, Rowman, Littlefield, 2013.

- Daryaee (Touraj), The Oxford Handbook of Iranian History, Oxford University Press, 2012.

- Davies (Gloria), Voicing Concerns: Contemporary Chinese Critical Inquiry, Rowman, Littlefield, 2001.

- Dennis (Joseph), Writing, Publishing, and Reading Local Histories in Ming China, University of Minnesota, 2004.

- Dillon (Michael), China's Muslim Hui Community, Migration, Settlement, and Sects, Curzon Press, 1999.

- Ding Hui-Qian, "Míng qīng běijīng chéngqū jí guānxiāng dìqū de qīngzhēnsì" (Muslim Mosques Inside Beijing City and the Outskirt Areas of the City in Ming and Qing Dynasties), Huizu Yanjiu, 1 (2015), 23-36.

- D'Ollone (Henri), "le Islam au Yunnan, Revue du Monde Musulman”, T'oung Pao, 1-4 (1908), 285-329.

- Dong Sai, Běijīng qūngzhēnsì jiànzhú zhuāngshì yìshù (Decorative Arts of Mosque's Architecture in Beijing), Master Thesis, Beijing: College of Education, Zhongyang Minzu University), 2009.

- Dreyer (Edward), Zheng He: China and the Oceans in the Early Ming Dynasty, 1405-1433, Pearson Longman, 2007.

- Drompp (Michael), Tang China and the Collapse of the Uighur Empire: A Documentary History, Brill's Inner Asian Library, Leiden: Brill, 2004.

- Duyvendak (Jan), "The True Dates of the Chinese Maritime Expeditions in the Early Fifteenth Century", T'oung Pao, Second Series, 34, Livr. 5 (1939), 341-413.

- Ebrey (Patricia), the Cambridge Illustrated History of China, Cambridge: Cambridge University Press, 1999.

- Ebrey (Patricia), Walthall (Anne), East Asia: A Cultural, Social, and Political History, Boston: Houghton Mifflin, 2006.

- Emiralioğlu (Pınar), "China and the Ottoman Imperial Project in the Sixteenth Century", The Journal of Ottoman Studies (OSMANLI ARASTTIRMALARI), 39 (2012), 161-187.

- Fan Lu, "Zhōngguó liăng lèi qīngzhēnsì duìbǐ qiăn xī" (Analysis on the comparison of two Chinese Types of Mosques), Jiànzhú Jiỳ̀, 1 (2013), 221-225.

- Fanyong Cong, Shì dà yŭ băo guó — yuán míngzhī jì de zhōng hán guānxì (Great Events and Protecting China - Sino-Korean Relations at the Turn of the Yuan and Ming Dynasties), Xiānggăng Jiàoyù Press, 2009.

- Franke (Wolfgang), The Reform and Abolition of the Traditional Chinese Examination System, Cambridge: East Asian Research Center, 1968.

- Frederic (Wakeman), The Great Enterprise: The Manchu Reconstruction of Imperial Order in Seventeenth-century China, University of California Press, 1985.

- Friedman (John), Figg (Kristen M.), Routledge Revivals: Trade, Travel and Exploration in the Middle Ages (2000): An Encyclopedia, Taylor, Francis, 2017.

- Fu (Zhengyuan), Autocratic Tradition and Chinese Politics, Cambridge University Press, 1993.

- Fu Tongxian, Zhōngguó huíjiào shř (History of Chinese Islam), Shangwu Press, 1934.

- Gaubatz (Piper), Beyond the Great Wall: Urban Form and Transformation on the Chinese Frontiers, Stanford University Press, 1996.

- Gladney (Dru), "Islam and Modernity in China. Secularization or Separatism?" in Chinese Religiosities. Afflictions of Modernity and State Formation, ed. Mayfair Mei-hui Yang, Berkeley: University of California Press, 2008.

- Gladney (Dru), Muslim Chinese: Ethnic Nationalism in the People's Republic, Harvard University: Asia Center, 1996.

- Graff (David A.), "Zheng He, China and The Oceans in The Early Ming Dynasty, 1405:1433", The Journal of Military History, 71 (2007), No.1, 213-214.

- Gregoratti (Leonardo), "The Parthians between Rome and China Gan Ying's mission into the West (1st century AD)", Academic Quarter: Journal for humanistic research, 4 (2012), 109-120.

- Hagras (Hamada), "An Ancient Mosque in Ningbo, China: Historical and Architectural Study", Journal of Islamic Architecture, 4 (2017), No. 3, 102-113. 
- Hagras (Hamada), “Xi' an Daxuexi Alley: Historical and Architectural study", Egyptian Journal of Archaeological and Restoration Studies "EJARS", 9 (2019), 97-113.

- Hagras (Hamada), Almasajid al'thrīat al baqīat fì madīnat beij̄̄n mundh alqarn alrrab'alhijrī (al 'shīr almīladī) wahatay nihayat alqarn althalīth shr alhijrī (alttas "shr almīladī) "drasat 'athriat muemarīat" (Beijing Mosques Since the fourth century until the Nineteen century A.D. "architectural and archaeological study"), (Ph.D. diss), University of Fayoum, Egypt.

- Hoon (Hum), Zheng He's Art of Collaboration: Understanding the Legendary Chinese Admiral from a Management Perspective, Singapore: Institute of Southeast Asian Studies, 2012.

- Houjin Liuxu, Jiutang shu, quan 16 ce (Old Book of Tang, 16 Volumes), Zhonghua Press, 1975.

- Hu (Fan), Der Islam in Shaanxi: Geschichte und Gegenwart Mit einer Untersuchung zum islamisch-christlichen Dialog in Zeiten der Globalisierung und des Ökumenismus (Islam in Shaanxi: History and the Present With an investigation into Islamic-Christian dialogue in times of globalization and ecumenism), Ph.D. diss, University of Bonn, Germany, 2008.

- Huang Minzhi, "Sòngdài jiātíng duìyú fójiào sìyuàn de gòngyăng_ yǐ shíkè wénzì wéi zhǔ" (Families Offer to Buddhist Temples as Seen in Extant Stone Inscriptions in the Case of the Song Dynasty), Zhōngguó shèhuì lìshǔ pínglùn, 2 (2004), 1-24.

- Huart (M. CL.), "Inscriptions arabes et persanes des mosquees chinoises de K'ai-fong-fou et de Singan-fou", T'oung pao, serie II, VI, E.G. Brill (1905), 261-320.

- Huzhen Hua, Mínzú wénhuà yánjiū wénjí (Studies on Ethnic Cultures), Zhongying Minzu University Press, 2006.

- Ibn Battuta ,Abū 'Abd al-Lāh Muḥammad ibn 'Abd al-Lāh 1-Lawātī ț-Ṭanğī (d 1369), Tuhfat an-Nuzzāar fi Gharā' ib al-Amșār wa 'Ajā' ib al-Asfär (A Gift to the Observers Concerning the Curiosities of the Cities and the Marvels Encountered in Travels), Beirut, 1992.

- Ioannides (Yannis), Zhang (Junfu), "Walled cities in late imperial China", Journal of Urban Economics, 97 (2017), issue C, 71-88.

- Israeli (Raphael), "Islam in China", Politics and Religion in Contemporary China, 5 (2012), No.2, 251-268.

- Israeli (Raphael), Muslims in China, a study in cultural confrontation, Curzon Press, 1980.

- Israeli, (Raphael), Islam in China, Religion, Ethnicity, Culture, Politics, published by Lexington Books, Boston, 2002.

- Jaschok (Maria), Shui (Jingjun), The History of Women's Mosques in Chinese Islam, A mosque of their own, Curzon Press, 2000.

- Jianai Zhou, Chang Bianzhou, Zhōng fëi guānxì shĭ wénxuăn (The History of Sino-African Relations Anthology), Huadong: Shifan University Press, 1989.

- Jianai Zhou, Chang Bianzhou, Zhōng fêi guānxì shĭ wénxuăn (The History of Sino-African Relations Anthology), Huadong: Shifan University Press, 1989.

- Jiang Bo, Qinli Yan, Fäxiàn cáng jīng dòng (Discover the caves of the Trip taka), Taiwan Library Press, 2007.

- Jin, Jitang, Zhōngguó huíjiào shĭ yánjiūu (Studies in the History of Chinese Islam), Beijing Chengda Shifan Xuexiao, 1935.

- Kangying (Li), The Ming Maritime Trade Policy in Transition, 1368 to 1567, Otto Harrassowitz Verlag, 2010.

- Kenzheakhmet (Nurlan), "The Place Names of Euro-Africa in the Kangnido", The Silk Road, 14 (2016), 106-125.

- Kurz (Johannes), China's Southern Tang Dynasty (937-976), Routledge, 2011.

- Lane (George), “The Dali Stele' In Kilic-Schubel, Nurten; Binbash, Evrim”, in Horizons of the World: Festschrift for Isenbike Togan / Hududu'l-Alem: İsenbike Togan'a Armağan, Istanbul: Ithaki Press, 2011. 1-39.

- Laufer (Berthold), "Chinese Muhammedan Bronzes, with a Study of the Arabic Inscriptions by Martin Sprengling”, Ars Islamica, 1 (1934), No. 2, 133-147.

- Leaning (M.), Pratt (D.), "Islam in China, From Silk Road to Separatism", The Muslim World, 102 (2012), 308-335. 
- Leslie (Donald), Islam in Traditional China, A Short History to 1800, Canberra, Canberra College of Advanced Education, 1986.

- Leslie (Donald), The Integration of Religious Minorities in China, The case of Chinese Muslims, Australian National University, 1998.

- Levathes (Louise), When China Ruled the Seas: The Treasure Fleet of the Dragon Throne, 1405-1433, Open Road Media, 2014.

- Li (Shujiang), Luckert, (Karl W.), Mythology, Folklore of the Hui, A Muslim Chinese People, SUNY Press, 1994.

- $\quad$ Li Shujiang and Karl W. Lukert, eds., Mythology and Folklore of the Hui: A Muslim Chinese People, New York: SUNY Press, 1994.

- Liang Longteng, "Qiānnián gǔsì jīngdiăn quánzhōu: Jì quánzhōu qīngjìng sì" (Millennium of Temple Classic Quanzhou Inscriptions of Quanzhou Qingjingsi Mosque), Shèngjì, 1 (2005), 4244).

- Li-hua Ying, Almasajid fi al-Sin (Mosques in China), Beijing: Foreign Languages Press, 1989.

- Lipman (Jonathan), Familiar Strangers: A History of Muslims in Northwest China, Washington, University of Washington Press, 1997.

- Liu (Jiayi), Study on the Auditing System of Socialism with Chinese Characteristics, John Wiley, Sons, 2017.

- Liu Wei, Níngxià huizú jiànzhú yìshù (Arts of Hui Architecture in Ningxia), Ningxia Renmin Press, 2006.

- Liu Zhi (d 1730), Tiänfāng zhì shèng shilù (The Veritable Records of Islam's Prophet), vol. 20 (huihui shou).

- Liuguo Liang, Zhōngguó gōngyè shǐ (Chinese Industrial History), Jiangsu kexue jishu Press, 1992.

- Liushu Xian, Rújiā zhéxué de diănfàn zhòng gòu yŭ quánshì (The Paradigm Reconstruction and Interpretation of Confucian Philosophy), Wanjuanlou, 2010.

- Liuzhi Ping, Zhōngguó yīsīlán jiào jiànzhú (Chinese Islamic Architecture), Beijing: Xinlian Press, 2008.

- Lixing Hua, ("Quánzhōu yīsīlán jiào yánjiū" (Studies on Islam in Quanzhou), Journal of Hui Minority, 2 (2010), 67-83.

- Lorge (Peter), The Reunification of China: Peace through War under the Song Dynasty, Cambridge University Press, 2015.

- Lu (Yongxiang), A History of Chinese Science and Technology, Volume II, Springer, 2014.

- Lu Bingjie, Zhōngguó jiànzhú yìshù quánjí, dì 16 juăn "ȳ̄sīlán jiào jiànzhú" (Collections Of Chinese Architecture, Volume 16, Islamic Architecture), Chinese Architecture Industry Press, 2003.

- Lubian Ting, "Lüè lùn sòngdài yīsīlán jiào jiànzhú" (On Islamic Architecture during Song Dynasty”, Mínzú lìshǐ xué yánjiū, 22 (2011), No. 2, 70-76.

- Lujin, Zhang Liming, Yīlăng: Dōngxī fāng wénmíng de huìhé diăn (Iran: The Convergence of Eastern and Western Civilizations), City University of HK Press, 2011.

- Ma Zhu, Qingzhēen zhǐnán (the compass or guide to Islam), Ningren Press, 1988.

- Man (John), Kublai Khan: The Mongol King Who Remade China, London; New York: Bantam Press, 2007.

- Mann (Susan), Cheng (Yu-Yin), Under Confucian Eyes: Writings on Gender in Chinese History, University of California Press, 2001.

- Marshallsay (Zaniah), "Between The State and Islam, Hui Muslim Women's Religious Participation in Public Space in China", in The APSA Conference 2010, Melbourne, 1-12.

- Mi (Shoujiang), You (Jia), Islam in China, Intercontinental Press, 2004.

- Miyazaki (Ichisada), China's Examination Hell: The Civil Service Examinations of Imperial China, New York: Weatherhill, 1976.

- Mote (Frederick), Imperial China 900-1800, Harvard University Press, 2003.

- Nappi (Carla), The Monkey and the Inkpot: natural history and its transformations in early modern China, Harvard University Press, 2010.

- Needham (Joseph), Science and Civilisation in China, Cambridge University Press, 1970. 
- Nujiang Zhou Nongyeju, Nujiang Zhou Xumuju, Nùjiāng zhōu nóng mù zhì (Nujiang Prefecture), Yunnan Minzu Press, 1999.

- Park (J. P.), Art by the Book: Painting Manuals and the Leisure Life in Late Ming China, University of Washington Press, 2017.

- Pelliot (Paul), "Les Grands Voyages Maritimes Chinois au debut du XVE Siecle”, T'oung Pao, 30 (1933), 237-452.

- Peter (Brent), The Mongol Empire, Book Club Associates, London, 1976.

- Peterson (Barbara), "The Ming Voyages of Cheng Ho (Zheng He) 1371-1433", The Great Circle, 16 (1994), No. 1, pp. 43-51.

- Pillsbury (Barbara), "Muslim History in China, a 1300 Chronology", Journal of The Institute of Muslim Minority affairs, 3/2 (1981), 10-29.

- Pletcher (Kenneth), The Britannica Guide to Explorers and Explorations That Changed the Modern World, The Rosen Publishing Group, 2009.

- Raphals (Lisa), New Belief: Religious transformation of China and Rome, ca. 1st-6th Centuries, Oxford University Press, 2017.

- Rockhill (W.), "Notes on the Relations and Trade of China with the Eastern Archipelago and the Coast of the Indian Ocean during the Fourteenth Century", T'oung Pao, Second Series Part V, 16 (1915), No. 5, 604-626.

- Rossabi (Morris), "Muslim and Central Asian Revolts", From Ming to Ch'ing, Yale University Press, 1979, pp. 169-199.

- Rossabi (Morris), Eurasian Influences on Yuan China, Institute of Southeast Asian Studies, 2013.

- Rossabi (Morris), From Yuan to Modern China and Mongolia: The Writings of Morris Rossabi, Brill, 2014.

- Rossabi (Morris), Khubilai Khan: His Life and Times, Berkeley: University of California Press, 1988.

- Schirokauer (Conrad), A Brief History of Chinese and Japanese Civilisation, South Melbourne, Nelson Thomson Learning Conrad, 1989.

- Song Ouyang Xiu, Song Qi Zhuan, Xīn táng shū, Dì èr 0 cè (New Book of Tang, Volume 38 to Volume 1215), Zhonghua Press, 1975.

- Steinhardt (Nancy), "China's Earliest Mosques", Journal of The Society of Architectural Historians, 67 (2008), No .3, 330-361.

- Sze (Tak Pui), Stupas in Medieval China: Symbol of the Buddha, Sacred Building, or Tombs, Ph.D. Degree, the Faculty of Graduate Studies (Asian Studies), the University of British Columbia, 2012.

- Tan (Ta Sen), Cheng Ho and Islam in Southeast Asia, Institute of Southeast Asian Studies, 2009.

- Tang Zongzheng, "Běijīng shì qīngzhēnsì diàochá (zhī qī) jǐn shén fâng jiē qīngzhēnsì" (Beijing Mosque Survey (No. 7) Jinshifang Street Mosque), Huijiao, 1939, 2 (3), 41-43.

- Taozi Zhen, Liăng sòng yuánxiāo cí yánjiü (Studies on Song and Yuan dynasty), Xiuwei Press, 2006.

- Terada Takanobu, Zhèng hé: Liánjié zhōngguó yǔ yīsīlán shìjiè de hánghăi jiāa (Zheng He: A Voyager Linking China to the Islamic World), translated by Zhuang jinghui, Haiyang Press, 1988.

- Tikhvinskiı̌ (S, L.), Perelomov (L, S.), China and her neighbors, from ancient times to the middle ages: a collection of essays, Moscow: Progress Publishers, 1981.

- Tong Xun, Běijīng zōngjiào wénhuà yánjiū (A Cultural Studies on Beijing Religions), Beijing: Zongjiao Wenhua Press, 2007.

- Tong Xun, Yīsīlán jiào yŭ běijīng qīngzhēnsì wénhuà (Mosques and Islamic Culture in Beijing), Beijing: Zhongyang Minzu University Press, 2003.

- Tsai (Shih-shan Henry), Perpetual Happiness: The Ming Emperor Yongle, University of Washington Press, 2011.

- Turnbull (Stephen), The Mongol Invasions of Japan 1274 and 1281, Bloomsbury Publishing, 2013. 
- Twitchett (Denis), Mote (Frederick), The Cambridge History of China: Volume 8, The Ming Dynasty, 8 (The Ming Dynasty 1368-1644), Part 2, Cambridge University Press, 1998.

- Vissiere (A.), "Le Seyyid Edjell Chams ed-Din Omar (1210-1279) et ses deux sepultures en Chine", Revue du Monde Musulman, 1-4 (1908), 330-346.

- Wahby (Ahmed), Islamic Architecture in China, Mosques of Eastern China, Master's Degree, The American University in Cairo, School of Humanities and Social Sciences, 2000.

- Wang (Rui), The Chinese Imperial Examination System: An Annotated Bibliography, Rowman, Littlefield, 2013.

- Wang (Wenfei), Zhou (Shangyi), "Growth and Decline of Muslim Hui Enclaves in Beijing", Eurasian Geography and Economics, 43 (2002), No.2, 104-122.

- Wang Daiyu (d 1658), Zhèngiiào zhēn quán (The True Explanation of the Right Religion), Ningxia Renmin Press, 1988.

- Wang Fenglei, Zhang Minjie, "Yuán dài yúnnán jiàoyù kăo" (Education and Examinations of Yunnan during Yuan Dynasty), Ménggŭ shǔ yánjiü, 8 (2005), 1-8.

- Wang Rong, Yang Lian, Xīyù kăochá yǔ yánjiū (Investigation and Research on Western Regions), Xinjiang Renmin Press, 1994.

- Wangqi Jun, Zhōngguó yuánlín tújiě cídiăn (Illustration Dictionary OF Chinese Garden), Jixie Gongye Press, 2007.

- Watt (James), Leidy (Denise), Defining Yongle: Imperial Art in Early Fifteenth-Century China, New York: the Metropolitan Museum of Art, 2005.

- Wilkinson (Endymion), Chinese History: A Manual, Cambridge: Harvard University, 2000.

- Wong (Dorothy), Chinese Steles: Pre-Buddhist and Buddhist Use of a Symbolic Form, University of Hawaii Press, 2004.

- Wu Jianwei, ed., Zhōngguó qīngzhēnsì zòng lăn (Overview of the Chinese Mosque), Ningxia Renmin Press, 1995.

- Wu Xuande, Míngdài jìnshì dì dilľ fênbù (Scholars of the geographical distribution of the Ming Dynasty), Zhongying University Press, 2009.

- Xin Yuanou, "Zhèng hé yǔ gēlúnbù xiànxiàng de bǐjiào yánjiū" (Comparison of Zheng He and Columbus Phenomenon), Shànghăi Zàochuán, 1 (2005), No. 63, 64-71.

- Xuezong Zheng, (2000), "dá luó sī zhī zhàn lìshǐ sùyuán—_áng yǔ dà shí băinián zhèngzhì guānxì shù lüè 651-751" (Historical Origins of the Talas Campaign, A Brief Construction on Political Relations between the Tang and Arab from 651 to 751), Zhongguo bianjiang shi di Yanjiu, 10 (2000), No. 4, 85-100.

- Yang Daye, "Míng qīng huízú jìnshì kăo lüè" (Hui Scholars of Ming and Qing Periods), Huizu Yanjiu, 1 (2005), 26-34).

- Yanghong Xun, Wanggui Xiang, Zhōngguó jiāngnán yuánlín fănggŭ (A Visit to Jiangnan Garden), Zhongguo zhanwang Press, 1984.

- Yanghuai Zhong, Zhèng hé yǔ wénmíng duìhuà (Zheng He and Civilized Dialogue), Ningxia Renmin Press, 2006.

- Yangwen Bi, "Shìqù de zhēnshí-huízú wěidà hánghăi jiā zhèng hé rénshēng suíxiăng" (Lost True: Hui the great Navigator Zheng He), Huizzú Wénxué, 6 (2010), No. 176, 42-45).

- Yao (Yifeng), Nanjing: Historical Landscape and Its Planning from Geographical Perspective, Springer, 2016, p. 18.

- Yin (Ma), China's Minority Nationalities, Beijing, 1994.

- Yu (Pauline), "Chinese Poetry and Its Institutions", in Hsiang Lectures on Chinese Poetry, 2, Montreal: Center for East Asian Research, McGill University, 2002/

- Yu (Shuishan), Chang'an Avenue and the Modernization of Chinese Architecture, University of Washington Press, 2013.

- Yu (Taishan), A History of the Relationships between the Western and Eastern Han, Wei, Jin, Northern and Southern Dynasties and the Western Regions, University of Pennsylvania, 2004.

- Yuzhen Gui , Leixiao Jing, Zhōngguó huízú jīnshí lù (Stone Monuments of Chinese Hui Minority), Ningxia Renmin Press, 2001.

- Zai Suo, Míng zhènghé zhĩ yánjiü (Studies on Zheng He of Ming Dynasty), Gaoxiong Dexin Press, 1980. 
- Zaichen Xingxiong, Chen Yunu, Zhènghé xià xīyáng guójì xuéshù yántăo huì lùnwén jí (Proceedings of the International Symposium on Zheng He's Voyages to Western Ocean), Taipei: Daoxiang Press, 2003.

- Zhang Chong-fu, "Cóng 'fān kè'dào 'huízú': Quánzhōu dìqū mùsīlín zúqún yìshí biànqiān de lìshǐ xǐngchá" (Barbarian Guests" to "Hui Minzu": The Historical Perspective on the Change of Ethnic Consciousness of Muslims in Quanzhou), in Hung Li-wan ed., Nation and Aborigines: History of Ethnic Groups in the Asia-Pacific Region, Taipei: Institute of Taiwan History Academia Sinica, 2009, 309-318.

- Zhang jian, "Xià xīyáng yǔ fêizhōu dòngwù de y̌̌njìn" (Introduction to the West African Animals), Xiya feizhou, 2 (2005), 65-71.

- Zhangting Yu, Míngshĭ, Huànguān chuán ȳ (History of Ming Dynasty, "The Eunuch"), Beijing: Zhonghua Book Press, 1975.

- Zheng Hao, Heming Li, Fènghuáng hào hánghăi rìjì (Notes on Nautical Phoenix), zhongxin Press, 2005.

- Zheng Yijun, Zhènghéquán chuán (Zheng He's Biography), Zhongguo Qingnian Press, 2005.

- Zhou Fazeng, Chen Longtao, Zhōngguó gǔdài zhèngzhì zhìdù shǐ cídiăn (Dictionary of History of Ancient Chinese Political System), Beijing: Shoudu shifan University Press, 1998.

- Zhouchun Jian, Sòng yuán míng qīng sì shū xué biān nián (The Song, Yuan, Ming and Qing Dynasties), Volume 2, Wan juanlou, 2012. 